\title{
In vitro propagation by axillary shoot proliferation, assessment of antioxidant activity, and genetic fidelity of micropropagated Paederia foetida L.
}

\author{
Biswaranjan Behera ${ }^{1}$, Priyajeet Sinha ${ }^{2}$, Sushanto Gouda ${ }^{3}$, Sakti K. Rath ${ }^{1}$, Durga P. Barik ${ }^{1}$, Padan K. Jena ${ }^{1}$, Pratap C. Panda ${ }^{2}$, \\ Soumendra K. Naik ${ }^{1 *}$ \\ ${ }^{1}$ Department of Botany, School of Life Sciences, Ravenshaw University, Cuttack, Odisha, India, ${ }^{2}$ Taxonomy and Conservation Division, Regional Plant Resource \\ Center, Bhubaneswar, Odisha, India, ${ }^{3}$ Department of Wildlife Science, AMITY University, Sector-125, Noida, Uttar Pradesh, India
}

\begin{tabular}{|c|c|}
\hline ARTICLE INFO & ABSTRACT \\
\hline $\begin{array}{l}\text { Article history: } \\
\text { Received on: October 11, } 2017 \\
\text { Accepted on: November } 15,2017 \\
\text { Available online: February } 17,2018\end{array}$ & $\begin{array}{l}\text { An efficient plant regeneration protocol through axillary shoot proliferation of nodal explants of a valuable medicinal } \\
\text { plant, Paederia foetida, has been developed. Highest shoot multiplication was found on Murashige and Skoog's } \\
\text { (MS) medium supplemented with } 3.0 \mathrm{mg} / 1 \mathrm{~N}^{6} \text {-benzylaminopurine. Upscaling of shoots was accomplished from } \\
\text { axenic nodal explants derived from primary in vitro regenerated shoots on fresh medium of the same composition. }\end{array}$ \\
\hline $\begin{array}{l}\text { Key words: } \\
\text { Antioxidant activity, } \\
\text { Clonal fidelity, } \\
\text { Inter simple sequence repeats } \\
\text { markers, } \\
\text { Micropropagation, } \\
\text { Paederia foetida }\end{array}$ & $\begin{array}{l}\text { Thus, we could obtain } 71-76 \text { shoots, in vitro, starting from a single node within } 11-12 \text { weeks. These shoots were } \\
\text { successfully rooted on } 1 / 2 \text { MS medium and acclimatized in soil. The biochemical fidelity was assessed by evaluating } \\
\text { the antioxidant activities of leaves of both field grown mother plant and micropropagated plants. The antioxidant } \\
\text { activities, as carried out by } 2 \text {, 2-diphenyl-1-picrylhydrazyl and metal chelating assay, of leaves collected from } \\
\text { micropropagated plants were at par with activity of leaves collected from mother plant. Most importantly, both } \\
\text { sources have significant antioxidant activities compared to the standard, butylated hydroxytoluene. Further, genetic } \\
\text { fidelity of the micropropagated plants with that of the mother plant was assessed by inter simple sequence repeats } \\
\text { markers, and their true-to-type nature was confirmed on the basis of monomorphic banding profile. This protocol has } \\
\text { potential to create large number of clonal plants with similar antioxidant activities as the natural plants and thus could } \\
\text { be useful for drug research and development. }\end{array}$ \\
\hline
\end{tabular}

\section{INTRODUCTION}

Paederia foetida L. (Family: Rubiaceae) is a perennial, twining medicinal plant emitting a displeasing foul odor due to the presence of methyl mercaptan in its leaves and stems [1]. The plant is widely used by the tribal people of India for the treatment of gastrointestinal disorder, stomachache, enterosis, flatulence, gastromegaly, piles, rheumatism, ulcers, and toothache [2,3]. This species also shows antiinflammatory [2,4], anticancerous [2], and antidiarrheal properties [2,5]. Fresh leaves are reported to have antioxidant properties $[2,6]$. Mild antibacterial and antifungal properties are also shown by the ethanol extract of the whole plant [7]. The valuable medicinal plant $P$. foetida is under stress in its natural habitat due to anthropogenic activities such as unsustainable harvesting by local medical practitioners, deforestation, urbanization, and habitat fragmentation [8]. Rightly,

*Corresponding Author

Soumendra K. Naik, Department of Botany,

School of Life Sciences, Ravenshaw University,

Cuttack - 753 003, Odisha, India.

Email: sknuu@yahoo.com this plant has been enlisted as a vulnerable plant in some states of India including Odisha [9]. The conventional method of propagation of $P$. foetida is usually through seeds. However, propagation can also be done by stem cuttings, which is a slow process [10] and not sufficient to meet commercial demands. Therefore, it has become imperative to propagate the plant species using alternative biotechnological methods which include tissue culture-mediated in vitro plant regeneration. In recent years, in vitro propagation has been reported in $P$. foetida through axillary shoot proliferation of nodal segments [8,11-13]. However, in these reports, the number of shoots regenerated is quite low to meet the commercial demand. Besides, plant regeneration through adventitious shoot organogenesis of $P$. foetida has also been reported by Behera et al. [14].

It is well known, by now, that reactive oxygen species (ROS) is believed to be a major factor of oxidative stress which in turn leads to various degenerative diseases including cancer, atherosclerosis, gastric ulcer, and arthritis [15]. Plants produce many antioxidant compounds which act as active oxygen scavengers [16]. Recently, the interest in natural antioxidants derived from plant sources has increased. Such plant-derived antioxidant compounds act as reducing hydrogen 
donors, singlet oxygen quencher, free radical scavengers, and chelating agents of prooxidant metals [17]. Furthermore, phytochemicals with antioxidant activity are associated with lower risk of mortality from several diseases [18]. Nevertheless, only limited information is available on antioxidant activity of leaves (using methanolic extract only) of $P$. foetida $[6,19]$.

Stress factors including wound, exposure to sterilants, and high concentrations in plant growth regulators under culture conditions may cause genetic variation among the regenerants [20]. Therefore, assessment of genetic fidelity and biochemical constituents including antioxidant activity among regenerants with that of mother plant is imperative if pharmaceutical use and genetic transformation studies are the ultimate aim. Till date, not a single protocol has been reported pertaining to the assessment of the genetic stability and biochemical fidelity of the field established micropropagated plants in $P$. foetida. Thus, this study was envisaged to develop an efficient plant regeneration protocol of $P$. foetida for constant supply of planting materials for reintroduction in wild and to provide raw materials with the uniform quality for pharmaceutical uses without disturbing the natural populations. Accordingly, the focus was also on the comparative antioxidant activities of leaves of mother and in vitrogenerated $P$. foetida plants using different solvent systems. Genetic fidelity of the micropropagated plants with that of the mother plant was also assessed by inter simple sequence repeats (ISSR) markers.

\section{MATERIALS AND METHODS}

\subsection{Micropropagation by Axillary Shoot Proliferation}

\subsubsection{Preparation of explants}

The healthy shoots from young growth flush were collected from a 2-year-old P. foetida plant maintained in the Department of Botany, Ravenshaw University, Cuttack, Odisha, India. The leaves of the shoots were trimmed, and the shoots were cut into single node pieces of 1.0$1.5 \mathrm{~cm}$ [Figure 1a]. These nodal explants were kept under running tap water for about 30 min followed by 10 min treatment with $5 \%(\mathrm{v} / \mathrm{v})$ aqueous solution of Teepol (Reckitt Benckiser Ltd., India) and then rinsed 5 times with double-distilled water. The surface sterilization of nodal explants was carried out inside a laminar airflow cabinet with $0.1 \%(\mathrm{w} / \mathrm{v})$ aqueous solution of mercuric chloride $\left(\mathrm{HgCl}_{2}\right.$, Himedia, India) for 3 min followed by 5 rinses with sterile double-distilled water.

\subsubsection{Culture media and conditions for axillary shoot proliferation}

The surface sterilized nodal explants were cultured on Murashige and Skoog's (MS) medium [21] supplemented with different concentrations $(0.5-5.0 \mathrm{mg} / \mathrm{l})$ of $\mathrm{N}^{6}$ - benzylaminopurine (BAP) or $(1.0-5.0 \mathrm{mg} / \mathrm{l})$ kinetin (Kin) singularly. The nodal segments were also cultured on $3.0 \mathrm{mg} / 1 \mathrm{BAP}$ supplemented with either $(0.1-0.5 \mathrm{mg} / \mathrm{l})$ gibberellic acid $\left(\mathrm{GA}_{3}\right)$ or $(0.1-1.0 \mathrm{mg} / \mathrm{l})$ 1-naphthaleneacetic acid (NAA) or $(0.1-1.0 \mathrm{mg} / \mathrm{l})$ indole-3-butyric acid (IBA). All the media used in this study were augmented with $30.0 \mathrm{~g} / 1$ sucrose and gelled with $8.0 \mathrm{~g} / 1 \mathrm{of}$ agar. The $\mathrm{pH}$ of all the media was adjusted to $5.8 \pm 0.1$ and autoclaved at $121^{\circ} \mathrm{C}$ and 15 pounds per square inch pressure for $17 \mathrm{~min}$. All the cultures were maintained at $25 \pm 1^{\circ} \mathrm{C}$ under $16 \mathrm{~h}$ photoperiod.

To enhance the number of shoots, the in vitro regenerated primary shoots from mature nodal explants were isolated, and leaves from the shoots were removed. The shoots were then cut into single node pieces $(0.8-1.0 \mathrm{~cm})$. These excised in vitro nodal explants [Figure 1b] were cultured on fresh media of the same composition as mentioned for axillary shoot proliferation using mature nodes.

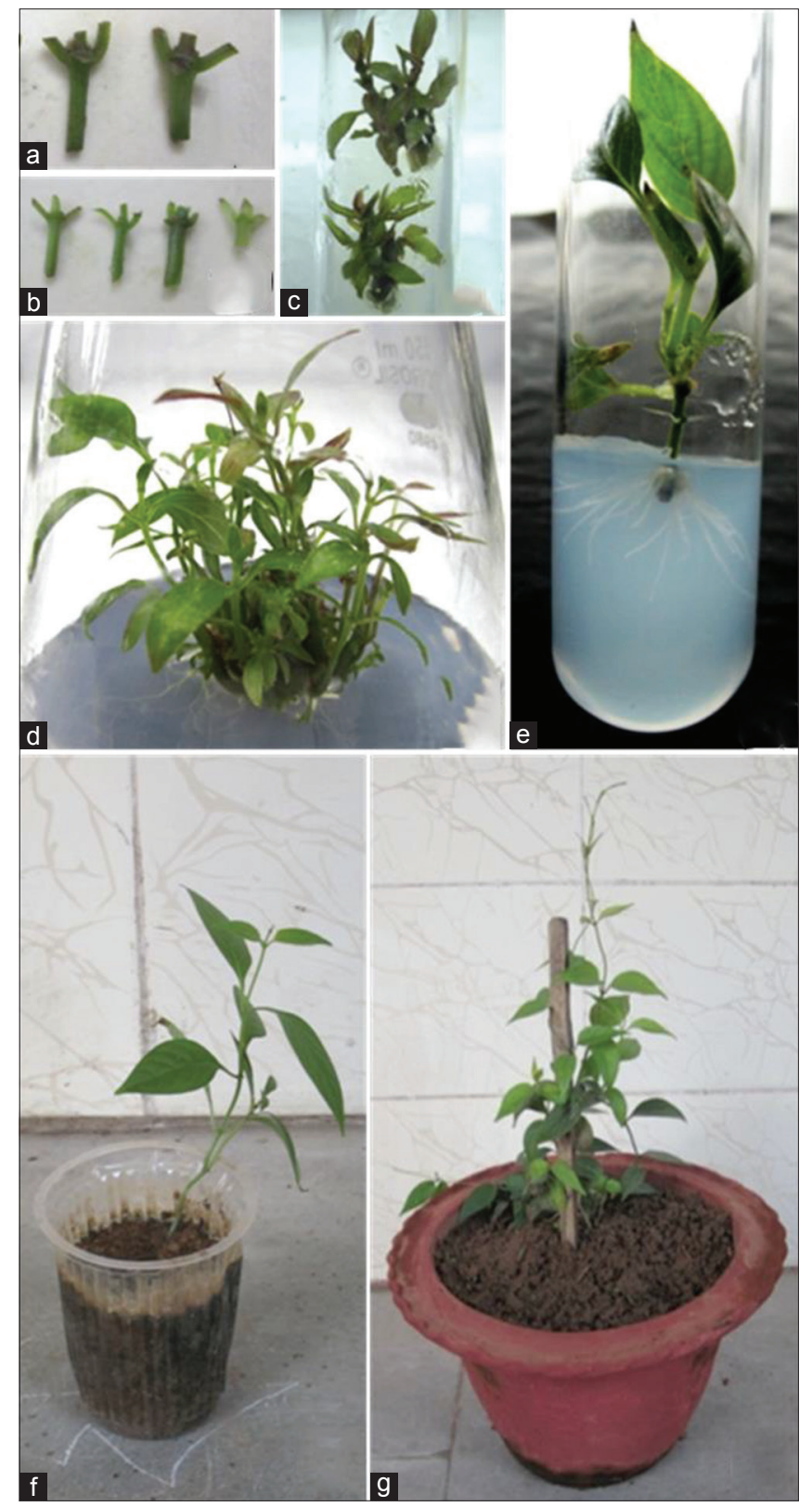

Figure 1: (a) Nodal explants excised from young growth flush of naturally grown Paederia foetida plant, (b) axenic nodal segments derived from primary in vitro shoots, (c) shoot proliferation from mature nodal explants on Murashige and Skoog's (MS) supplemented with $3.0 \mathrm{mg} / \mathrm{l} \mathrm{N}^{6}$ benzylaminopurine (BAP), (d) proliferation of multiple shoots from axenic nodal explant on MS augmented with $3.0 \mathrm{mg} / 1$ BAP medium, (e) rooting of in vitro regenerated shoot on $1 / 2$ MS medium after 25 days of culture, (f) an acclimatized plant in soil:sand (1:1) substrate (g) acclimatized plant of

P. foetida in clay pot.

\subsubsection{Rooting of axenic shoots and acclimatization of in vitro regenerated plantlets}

The healthy and elongated shoots were excised and individually implanted either on $1 / 4 \mathrm{MS}$ or $1 / 2 \mathrm{MS}$ or MS medium devoid of any growth regulators for rooting of shoots. The plantlets with well-developed roots were removed from culture media, washed carefully under tap water to remove traces of agar and medium. They were then transferred 
to small plastic pots $(6.5 \mathrm{~cm}$ dia) containing sterile soil and sand (1:1) and were covered with polyethylene bags. These plantlets were kept in the culture room under the same controlled environmental conditions as described earlier in axillary shoot proliferation experiment. After a week's time, holes were punched in the polyethylene bags to reduce the humidity. The plantlets were watered once in 3 days with sterile distilled water. After 3 weeks, plants were transferred outdoors and kept under the shade for about 1 week. They were then transferred to clay pots having garden soil and kept for 2 weeks before transfer under full sun. After 3 months, the potted plants were transplanted in field.

\subsection{Antioxidant Activity of Leaves}

\subsubsection{Preparation of leaf extracts}

Crude extracts of hexane (99\%), acetone (99\%), methanol (99\%), and aqueous were obtained by extracting $25 \mathrm{~g}$ of fine powder from shade dried leaves of both mother and micropropagated $P$. foetida plants with $250 \mathrm{ml}$ of respective solvents in a Soxhlet apparatus for $48 \mathrm{~h}$. Extracts were filtered through Whatman no.1 filter paper and evaporated to dryness. The extracts were stored at $4{ }^{\circ} \mathrm{C}$ for further analysis.

\subsubsection{2, 2-diphenyl-1-picrylhydrazyl (DPPH) assay}

The free radical scavenging activities of different leaf extracts were carried out by DPPH antioxidant test as described by Farhan et al. [22] with slight modifications. About $1 \mathrm{ml}$ of different concentrations (50, 75 , and $100 \mu \mathrm{g} / \mathrm{ml}$ ) of diluted extracts of leaves in methanol was added to $1.0 \mathrm{ml}$ of DPPH $(0.15 \mathrm{mM}$ in methanol), and at the same time, a control consisting of $1.0 \mathrm{ml}$ DPPH with $1.0 \mathrm{ml}$ methanol was prepared. Reaction mixtures were mixed and incubated in the dark for $30 \mathrm{~min}$ at room temperature. After that the absorbance was measured at $517 \mathrm{~nm}$. The butylated hydroxy toluene (BHT) was used as a standard, and the methanol was used as blank.

$\%$ scavenging activity $=[($ Absorbance control-Absorbance sample $) /$ (Absorbance control) $] \times 100$

\subsubsection{Metal chelating activity}

Ferrous ion chelating activity was assessed as described by Patra et al. [23]. Different concentrations (50, 75, and $100 \mu \mathrm{g} / \mathrm{ml})$ of plant extracts were added to $0.5 \mathrm{ml}$ of ferrous chloride $(2 \mathrm{mM})$ and left for incubation at room temperature for $5 \mathrm{~min}$. Then, the reaction was initiated by adding $0.1 \mathrm{ml}$ of ferrozine (3-[2-pyridyl]-5, 6-diphenyl-1, 2, 4-triazine-4, 4'-disulfonic acid Na-salt) (5 mM), and the mixture was adjusted to $3.0 \mathrm{ml}$ with deionized water, shaken vigorously, and incubated at room temperature for $10 \mathrm{~min}$. Absorbance was measured at $562 \mathrm{~nm}$. BHT was used as positive control. Metal chelating activity of the plant extracts was calculated from following equation.

Metal chelating effect $(\%)=[($ Absorbance control-Absorbance sample $) /($ Absorbance control $)] \times 100$

\subsection{Statistical Analysis}

For axillary shoot proliferation from mature nodal explants and axenic nodal explants experiments, eight culture vessels with two explants each and ten culture vessels with one explant each were used, respectively. Ten tubes containing one explant each were taken for rooting experiment. All these experiments were repeated thrice. Observations were recorded regarding the frequency of shoot proliferation and rooting as well as the number of shoots per explant, shoot length, roots per shoot, and root length. The antioxidant experiments were carried out 3 times. The analysis of variance was carried out to analyze the data. Duncan's new multiple range test [24] was used to designate means with significant effect.

\subsection{ISSR Analysis of Micropropagated Plants}

Ten micropropagated plants were selected randomly to assess their genetic fidelity with that of the mother plant. In the present investigation, a polymerase chain reaction (PCR)-based molecular markers, namely, ISSR was used for analysis of the genetic fidelity. The total genomic DNA of mother plant as well as the in vitro regenerated plants was isolated separately from $2 \mathrm{~g}$ of the young leaf tissues using the modified cetyl-trimethyl-ammonium-bromide method [25]. The quality and quantity of the isolated genomic DNA were estimated on $0.8 \%$ agarose gel by comparing band intensities. Twenty ISSR primers designed by us (Genei-Merck, India) were randomly selected for ISSR analysis, of which 15 primers were chosen for the clonal fidelity analysis as they produced clear and reproducible bands. PCR amplification for ISSR analysis was carried out using a total volume of $25 \mu \mathrm{l}$ of PCR mixture containing $1.0 \mu \mathrm{l}$ of $20 \mathrm{ng}$ template DNA, $2.5 \mu$ of 10x PCR buffer (100 mM Tris $\mathrm{HCl} \mathrm{pH} 8.3,500 \mathrm{mM}$ $\mathrm{KCl}$ and $0.1 \%$ gelatin), $1.0 \mu \mathrm{l}$ of $1.5 \mathrm{mM} \mathrm{MgCl}, 0.2 \mu 1$ of $100 \mathrm{mM}$ (200 $\mu \mathrm{M}$ each) dNTPs, $1.0 \mu \mathrm{l}$ of primer ( $15 \mathrm{pmole} / \mu \mathrm{l}), 0.1 \mu \mathrm{l}$ of $5 \mathrm{U} / \mu \mathrm{l}$ Taq DNA polymerase (Genei-Merck, India), and $19.2 \mu 1$ of molecular biology grade water (Hi-Media, India). The DNA amplification was carried out in a thermal cycler (Applied Biosystem, Model 9700) with the following amplification reaction steps: Initial denaturation step at $94^{\circ} \mathrm{C}$ for $5 \mathrm{~min}$, followed by 42 cycles of $1 \mathrm{~min}$ denaturation of template DNA at $92^{\circ} \mathrm{C}, 1 \mathrm{~min}$ primer annealing at a temperature $5^{\circ} \mathrm{C}$ lower than melting temperature for each primer, 2 min primer extension at $72^{\circ} \mathrm{C}$, and final extension step of $7 \mathrm{~min}$ at $72^{\circ} \mathrm{C}$. The PCR products obtained were electrophoresed on $1.5 \%$ agarose gel (GeNei) along with Medium Range DNA Ruler (100 bp - 5 kb) (Genei-Merck, India) using 1x TAE buffer ( $\mathrm{pH}$ 8.0). The gels were photographed with a gel documentation system (Bio-Rad, USA) to record the number and size of the amplified products. ISSR amplifications were carried out twice using each primer to check the reproducibility. Only clear bands were scored manually, and the amplicons with the same migration were considered homologous fragments irrespective of their intensity.

\section{RESULTS AND DISCUSSION}

\subsection{Axillary Shoot Proliferation from Mature Nodal Explant}

In this study, a linear relationship was observed between the increasing concentration of the cytokinins (BAP or Kin) and percentage of shoot proliferation as well as number of shoots per nodal explant [Table 1]. This increasing trend was observed up to $3.0 \mathrm{mg} / 1 \mathrm{BAP}$ or $2.0 \mathrm{mg} / \mathrm{l} \mathrm{Kin}$, and afterward, the frequency declined significantly. Probably, this could be due to excessive cytokinin loading, thereby irreversibly altering the endogenous growth regulator balance. BAP was found to be a superior cytokinin than Kin. The highest percentage shoot regeneration and maximum number of shoots per nodal segment were recorded with MS supplemented with BAP at an optimal level of $3.0 \mathrm{mg} / 1$ [Table 1]. On this media, $89.58 \%$ of nodal explants showed bud break within 8-10 days, and from each node, an average of 3.09 shoots developed [Figure 1c] within 30 days. Unlike the present study, where $3.0 \mathrm{mg} / 1$ BAP was optimum, Amin et al. [12] found a lower concentration of BAP $(1.0 \mathrm{mg} / \mathrm{l})$ to be more effective for axillary shoot proliferation in $P$. foetida. At the same time, contrary to the present findings, Alam et al. [11] reported the use of two cytokinins, i.e., BAP $(1.0 \mathrm{mg} / \mathrm{l})+$ Kin $(0.5 \mathrm{mg} / \mathrm{l})$ for shoot multiplication from nodal segments of $P$. foetida. Thus, the effect of plant growth regulators is conflicting on 
Table 1: Effect of plant growth regulators on shoot proliferation from mature nodal explants of Paederia foetida

\begin{tabular}{|c|c|c|c|c|c|c|c|}
\hline \multicolumn{5}{|c|}{ MS basal medium + plant growth regulators (mg/l) } & \multirow[t]{2}{*}{$\%$ shoot development } & \multirow[t]{2}{*}{ Number of shoots/ explant } & \multirow[t]{2}{*}{ Shoot length $(\mathrm{cm})$} \\
\hline BAP & Kin & $\mathrm{GA}_{3}$ & NAA & IBA & & & \\
\hline - & - & - & - & - & $14.58^{\mathrm{r}}$ & $1.42^{\text {mnop }}$ & $1.60^{\mathrm{mno}}$ \\
\hline 0.5 & & & & & $52.08^{\mathrm{lmno}}$ & $1.56^{\mathrm{lmn}}$ & $2.05^{\mathrm{jkl}}$ \\
\hline 1.0 & & & & & $72.91^{\mathrm{gf}}$ & $2.14^{\mathrm{fghi}}$ & $2.40^{\mathrm{fghi}}$ \\
\hline 1.5 & & & & & $79.16^{\text {cdef }}$ & $2.28^{\mathrm{efg}}$ & $2.52^{\mathrm{fgh}}$ \\
\hline 2.0 & & & & & $81.25^{\text {abcde }}$ & $2.41^{\text {def }}$ & $2.60^{\mathrm{fg}}$ \\
\hline 3.0 & & & & & $89.58^{\mathrm{a}}$ & $3.09^{\mathrm{ab}}$ & $3.75^{\mathrm{abc}}$ \\
\hline 3.5 & & & & & $85.41^{\mathrm{abc}}$ & $2.80^{\mathrm{abc}}$ & $3.30^{\mathrm{d}}$ \\
\hline 4.0 & & & & & $70.83^{\text {gh }}$ & $2.55^{\mathrm{de}}$ & $2.75^{\mathrm{ef}}$ \\
\hline 4.5 & & & & & $62.50^{\mathrm{ij}}$ & $2.16^{\mathrm{fgh}}$ & $2.00^{\mathrm{ijklm}}$ \\
\hline 5.0 & & & & & $56.25^{\mathrm{jklm}}$ & $1.85^{\mathrm{hijk}}$ & $1.80^{\mathrm{jklmn}}$ \\
\hline & 4.0 & & & & $47.90^{\text {no }}$ & $1.65^{\mathrm{km}}$ & $1.38^{\text {nopqr }}$ \\
\hline & 5.0 & & & & $33.33^{p}$ & $1.31^{\text {nop }}$ & $1.14^{\text {parstu }}$ \\
\hline 3.0 & & 0.1 & & & $85.41^{\mathrm{abc}}$ & $2.41^{\mathrm{def}}$ & $2.07^{\mathrm{ijk}}$ \\
\hline 3.0 & & 0.25 & & & $87.50^{\mathrm{ab}}$ & $3.11^{\mathrm{a}}$ & $4.04^{\mathrm{a}}$ \\
\hline 3.0 & & 0.5 & & & $85.41^{\mathrm{abc}}$ & $2.73^{\mathrm{cd}}$ & $4.01^{\mathrm{ab}}$ \\
\hline 3.0 & & & 0.1 & & $79.16^{\text {cdef }}$ & $2.10^{\text {fghij }}$ & $1.87^{\mathrm{jklmn}}$ \\
\hline 3.0 & & & 0.5 & & $62.50^{\mathrm{ij}}$ & $1.66^{\mathrm{klm}}$ & $1.50^{\text {nopq }}$ \\
\hline 3.0 & & & 1.0 & & $50.00^{\mathrm{mno}}$ & $1.25^{\text {nop }}$ & $0.75^{\mathrm{u}}$ \\
\hline 3.0 & & & & 0.1 & $58.33^{\mathrm{jkl}}$ & $1.78^{\mathrm{kl}}$ & $1.20^{\text {qrstu }}$ \\
\hline
\end{tabular}

Means with common letters within columns are not significantly different at $P \leq 0.05$, according to Duncan's new multiple range test. BAP: ${ }^{6}$-benzylaminopurine, MS: Murashige and

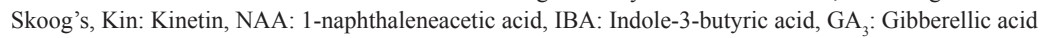

axillary shoot proliferation in $P$. foetida. These types of results could be due to the difference in the genotype of the plant and/or age of the explant [26,27]. Besides, this could also be attributed to variation in the physiological condition of the plant due to time/season of explant collection. Such difference has also been reported in other plant species [26]. Further, a combination of cytokinin and auxin $(2.0 \mathrm{mg} / \mathrm{l}$ $\mathrm{BAP}+0.5 \mathrm{mg} / \mathrm{l} \mathrm{NAA}$ ) was used by Srivastava and Srivastava [8] for micropropagation of $P$. foetida through nodal culture. However, in our study, the addition of different concentrations of auxin either NAA or IBA in the optimal shoot regeneration medium (MS + 3.0 mg/l BAP) failed to enhance the frequency of shoot regeneration as well as the number of shoots per nodal explant. In NAA supplemented media, a fair amount of callus was observed at the basal region of the explants. Similar results have also been reported in a number of plant species including Cedrela fissilis [28], Oroxylum indicum [29], and Barleria greenii [30]. The antagonistic influence of auxin for BAP supplemented media for axillary shoot proliferation may be due to exogenous application of auxin. These auxins probably decrease the cytokinin levels by promoting metabolic inactivation of BA by N-glucosylation or regulating cytokinin oxidase genes that encode proteins capable of degrading cytokinin [31,32]. Besides, it is possible that exogenous application of auxin to BA supplement basal media strengthened apical dominance at the cost of axillary shoot proliferation [30]. $\mathrm{GA}_{3}$ supplementation to MS medium also failed to enhance the result.

\subsection{In Vitro Multiplication of Shoots}

With an aim to upscale the number of shoots, further prolific shoot cultures were established by culturing the nodal segments derived from primary in vitro shoots on different culture media. About $93.33 \%$ axenic nodes exhibited multiple shoot regeneration with an average of 19.10 shoots per node in 45-50 days on MS supplemented with $3.0 \mathrm{mg} / 1$ BAP [Table 2 and Figure 1d]. The average shoot length was recorded to be $3.70 \mathrm{~cm}$. Thus, it was possible to regenerate about 71-76 shoots within 11-12 weeks starting from a single mature nodal segment. While in earlier report on $P$. foetida, the number of shoots regenerated per node was found to be 4.5 [12], 12.66 [8], 2.53 [11], and 14.71 [13]. Establishments of such prolific shoot cultures for upscaling of shoots by in vitro nodal multiplication was also reported in many medicinal plant species including Zehneria scabra [33] and Withania somnifera [34].

\subsection{Rooting of Shoots and Plantlet Acclimatization}

Inclusion of an auxin to the basal medium is usually necessary for rooting. However, in the present study, growth regulator-free MS or $1 / 2$ MS or $1 / 4$ MS was sufficient for rooting of in vitro regenerated shoots [Table 3]. Half-strength MS devoid of any growth regulators induced best rooting, where $93.33 \%$ shoots exhibited rooting with 25.71 roots/ shoot [Figure 1e]. On this optimal rooting medium, the average root 
Table 2: Influence of plant growth regulators on axillary shoot proliferation from in vitro nodal explants of Paederia foetida

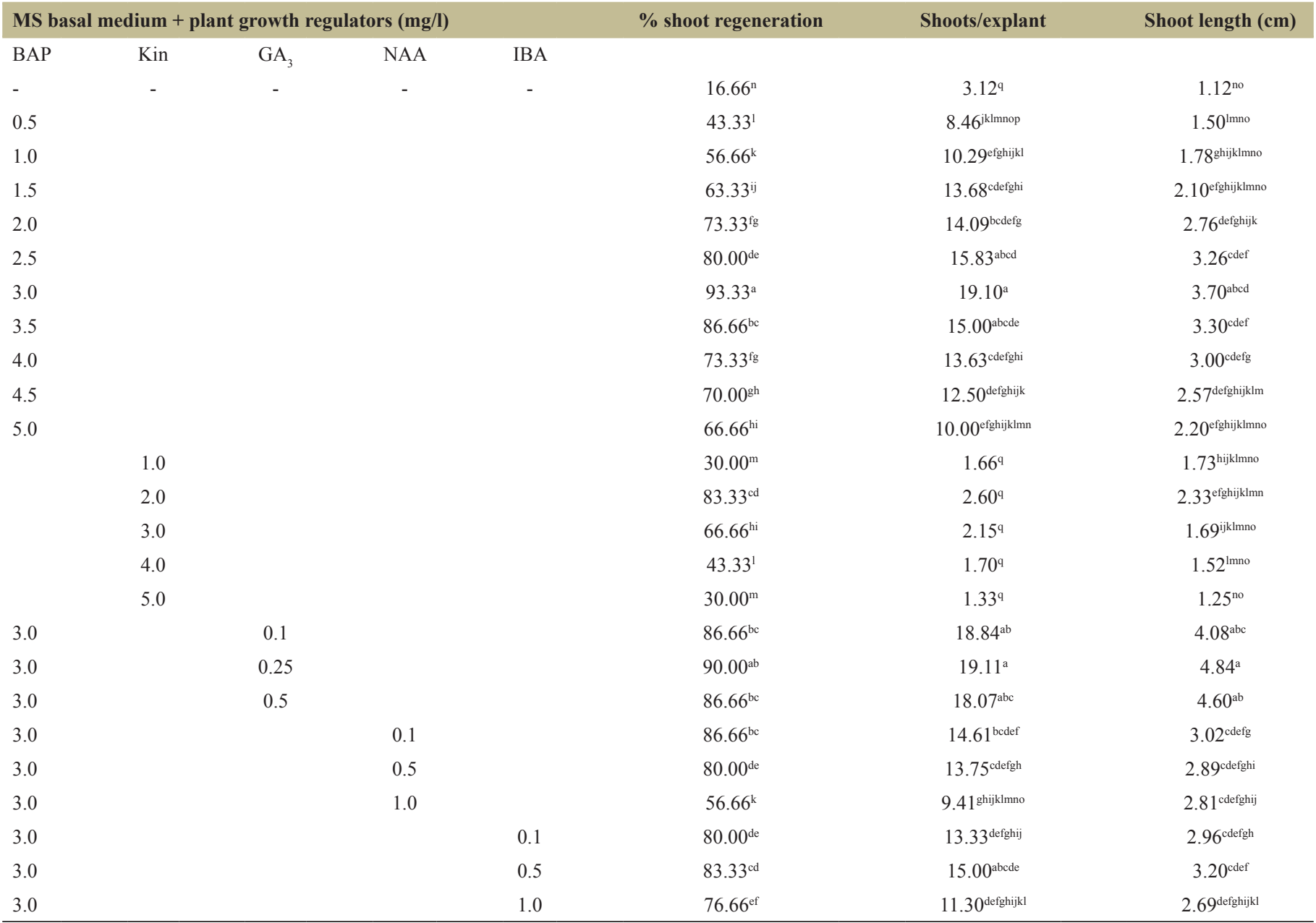

Means with common letters within columns are not significantly different at $P \leq 0.05$, according to Duncan's new multiple range test. BAP: ${ }^{6}$-benzylaminopurine, MS: Murashige and

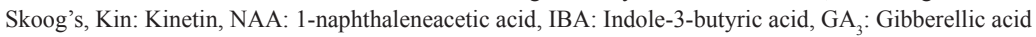

Table 3: Rooting of in vitro regenerated shoots of Paederia foetida

\begin{tabular}{lccc} 
Media & \% rooting & Roots/shoot & Root length (cm) \\
$1 / 4 \mathrm{MS}$ & $80.00^{\mathrm{b}}$ & $15.83^{\mathrm{b}}$ & $2.21^{\mathrm{a}}$ \\
$1 / 2 \mathrm{MS}$ & $93.33^{\mathrm{a}}$ & $25.71^{\mathrm{a}}$ & $2.99^{\mathrm{a}}$ \\
$\mathrm{MS}$ & $66.66^{\mathrm{c}}$ & $15.50^{\mathrm{b}}$ & $2.25^{\mathrm{a}}$ \\
\hline
\end{tabular}

Means with common letters within columns are not significantly different at $P \leq 0.05$, according to Duncan's new multiple range test. MS: Murashige and Skoog's

length was recorded to be 2.99 in 25 days. However, in earlier reports, the rooting was best seen on IBA $(0.1 \mathrm{mg} / \mathrm{l})(3.5$ roots per shoot; Amin et al. [12]), $(0.5 \mathrm{mg} / \mathrm{l})(2.0$ roots per shoot; Alam et al. [11]), $(0.04 \mu \mathrm{M})$ (6.41 roots per shoot; Thirupathi et al. [13]). Ninety percent plantlets were successfully acclimatized after transfer to soil:sand (1:1) substrate [Figure 1f] and cent percent of them were successfully transferred to pots containing garden soil [Figure 1g]. Hundred percent survival of plantlets was recorded on subsequent transfer to soil in field.

\subsection{Antioxidant Study}

Antioxidant activity of hexane, acetone, methanol, and aqueous leaves extract of both mother and micropropagated $P$. foetida plant were estimated by DPPH scavenging and metal chelating ferrozine activity. All the four solvent extracts of both leaves sources showed significantly higher DPPH activity in comparison to the standard BHT at all the 3 concentrations $(50,75$, and $100 \mu \mathrm{g} / \mathrm{ml})$ [Figure 2a and b]. The iron chelating capacity (ferrozine scavenging activity) of all the four solvent extracts of leaves of both sources was also significantly higher in comparison to the standard BHT in all the three $(50,75$, and $100 \mu \mathrm{g} / \mathrm{ml}$ ) concentrations [Figure $2 \mathrm{c}$ and d]. The leaf extracts exhibited an increase in the percentage of scavenging property with an increase in the concentration of extracts. DPPH assay is a widely used model system for assessment of scavenging activity of several natural and synthetic compounds. DPPH radical is scavenged by antioxidants through the donation of protons forming the reduced DPPH [35]. The chelating of ferrous ions by leaf extract was studied, as metal chelation is one of the important properties of antioxidants. Transition metals including iron play a key role in oxygen radical reactions and subsequently cause oxidative damage in biomolecules such as protein and DNA [36]. The result of our study showed that solvent extracts of leaves from both sources exhibit significant antioxidant activity. Furthermore, the antioxidant activity of leaves of in vitro generated P. foetida plants is at par with that of the mother plant. Cellular damage or oxidative injury arising from free radicals of ROS now appears to be one of the key factors for a number of human disease, such as inflammation, cancer, atherosclerosis, neurodegenerative disease, and aging [15,37]. Hence, the present study concludes that even the leaves of micropropagated $P$. foetida can be used as a source of lead 


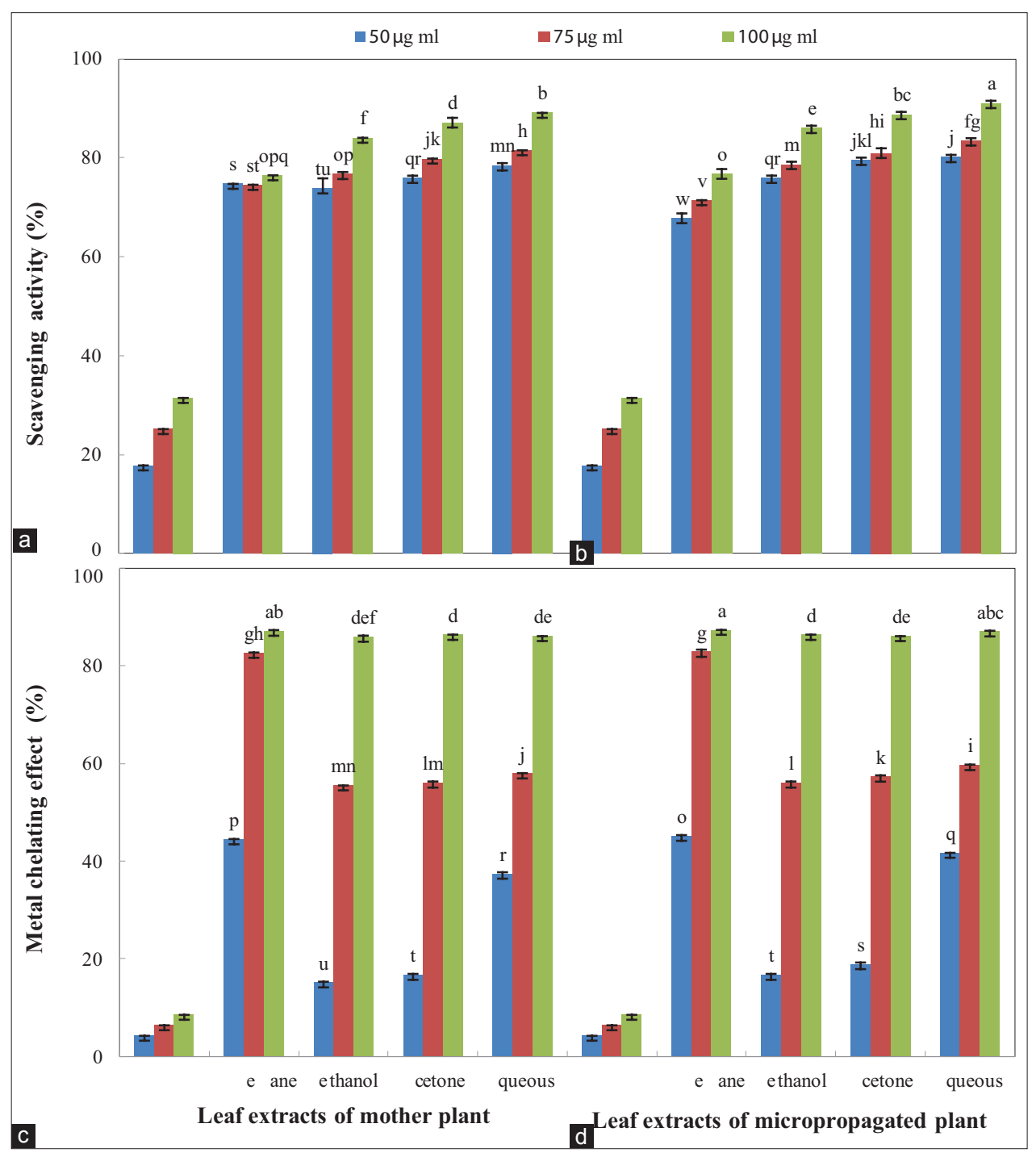

Figure 2: Antioxidant activity; 2, 2-diphenyl-1-picrylhydrazyl radical scavenging activity of leaf extracts of (a) mother plant and (b) micropropagated plant; and metal chelating activity of leaf extracts of (c) mother plant and (d) micropropagated plant of Paederia foetida. Bars with common letters are not significantly different at $P \leq 0.05$, according to Duncan's new multiple range test.

molecules for the formulation of drugs to target diseases originated due to oxidative damage.

Oral administration of different doses (100, 250, and $500 \mathrm{mg})$ of methanolic leaf extracts of naturally grown $P$. foetida significantly improved the level of superoxide dismutase, catalase, and glutathione peroxidase in induced diabetic group of rats [3]. Hence, antioxidant treatment may be beneficial for diabetic patient, and $P$. foetida plant will be a major help in this regard [3]. Antioxidant potential by DPPH radical scavenging activity of methanolic leaf extracts of naturally grown $P$. foetida has also been reported by Nayak et al. [19], and antioxidant activity by ABTS radical cation assay of the methanol extract of the whole plant of $P$. foetida has been reported by Osman et al. [6]. In contrast to above works, our work suggests the antioxidant activity of four different solvent extracts (hexane, acetone, methanol, and aqueous) of leaves of $P$. foetida. Moreover, the present research exhibits for the first time a comparative account of antioxidant activity of both mother and in vitro generated $P$. foetida plants.

\subsection{Assessment of Genetic Fidelity by ISSR}

Biochemical as well as genetic fidelity of the tissue cultured raised plants is essential for their commercial utilization. Regeneration of plants through axillary shoot proliferation of nodal explants with pre-existing meristems usually does not, at least theoretically, result in the production of somaclonal variants [38]. Thus, in this study, we have chosen nodal segments as our starting experimental material. The regenerated plants in this study were morphologically similar to the mother plant, and there were no detectable variations among them. However, at times, the structural difference in the gene products is not adequate to modify the phenotypic characters enough for visual detection [39]. At the same time, morphological markers are influenced by environmental conditions and are thus unreliable. Hence, it is not always possible to detect the variation at the genetic level by morphological markers. Besides, instances of regeneration of variants from organized meristems have also been reported [40]. Different factors other than explant types, such as plant growth regulators, temperature, light, and length of culture, also influence 
the development of variants in vitro [20]. Synthetic plant growth regulators including BAP (the best growth regulator in this study) have been most often considered to be accountable for genetic variability [20]. Under such circumstance, it is imperative to assess the clonal fidelity of the micropropagated plants using molecular markers as they are independent of environment, stable, reliable, reproducible, and heritable. By now, the utility of PCR-based ISSR markers for assessment of the genetic stability of the tissue culture raised plants has been well exemplified in a number of plant species $[41,42]$. This PCR-based molecular marker has been preferred over other molecular markers including restriction fragment length polymorphism, amplified fragment length polymorphism, and simple sequence repeats due to its simplicity, quickness, reproducibility, ability to show high polymorphism, cost-effectiveness, non-radioactive nature, requirements for the small amount of DNA, and non-requirement of prior knowledge of sequence information of the genome [43].

Keeping all these in view, an attempt was made to assess the genetic fidelity of the ten randomly selected micropropagated plants with that of the mother plant using ISSR markers. In this study, a total of 20 ISSR primers were used for the preliminary screening of genetic fidelity, of which only 15 primers were selected for final fingerprinting analysis as they gave clear and reproducible bands. The 15 ISSR primers amplified a total of 80 bands with an average of 5.33 bands per primer. The number and size of scorable amplicons varied from 02 (Oligo 8[a]) to 8 (PCP2 and PCP6) and $300 \mathrm{bp}$ (PCP9) to $2500 \mathrm{bp}$ (Oligo11[a]), respectively. The details of the amplicons for each ISSR primers have been presented in Table 4. All the bands generated from in vitro regenerated plants through ISSR markers were found to be monomorphic and similar to those of the mother plant indicating the true to typeness of the clones [Figure $3 \mathrm{a}$ and $\mathrm{b}$ ]. This result suggests the use of axillary shoot proliferation of nodal explant as preferred mode for production of true-to-type plants in P. foetida.

\section{CONCLUSIONS}

We have developed an effective and high-frequency plant regeneration protocol for an important medicinal plant, $P$. foetida. Besides, the comparative study reveals that the antioxidant activity of the leaves of in vitro generated $P$. foetida plants is at par with that of the leaves of mother plant. Further, to the best of our knowledge, this is the first report where the clonal fidelity of micropropagated plants of $P$. foetida has been confirmed with the use of molecular marker. This protocol

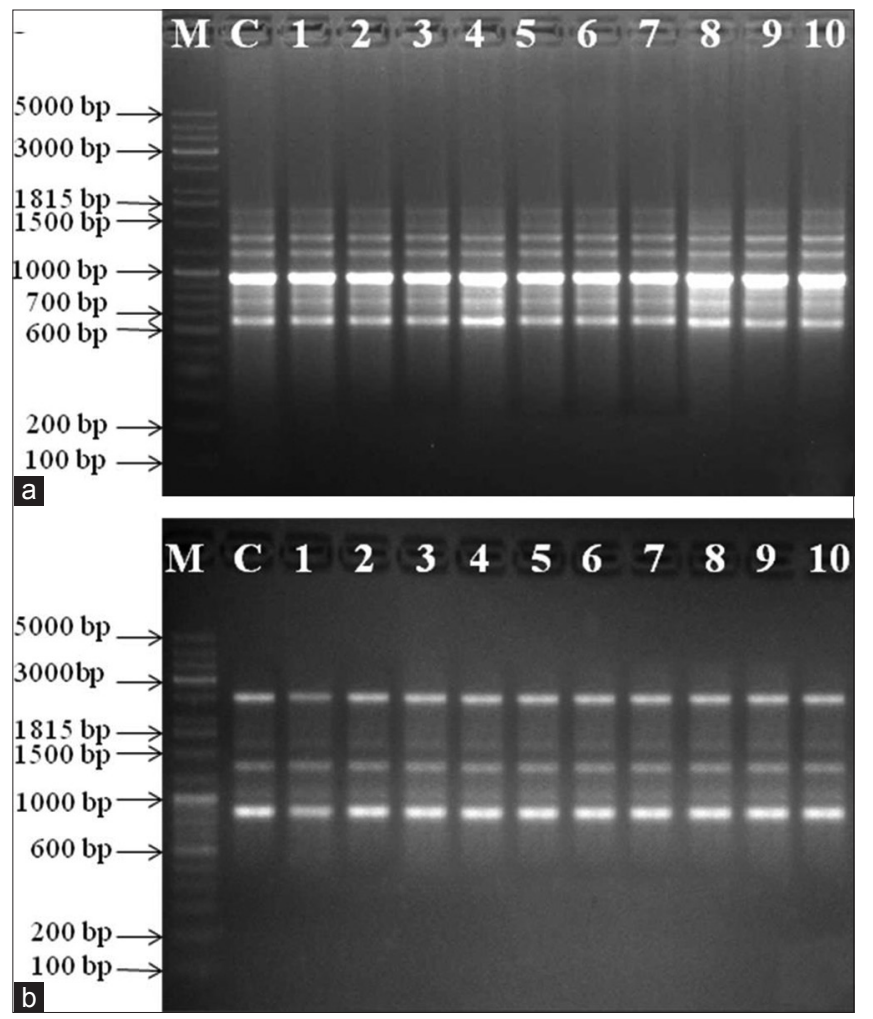

Figure 3: Inter simple sequence repeats amplification profile of mother plant and in vitro regenerated plants of Paederia foetida using (a) PCP 1 primer and (b) Oligo 11(a) primer. Lane M is the marker, Lane C mother (control) plant, Lane 1-10 micropropagated plants.

Table 4: Details of ISSR primers with their sequences, melting temperature, annealing temperature, size, and number of bands generated during the assessment of genetic fidelity of micropropagated plants with that of the mother plant of Paederia foetida

\begin{tabular}{|c|c|c|c|c|c|}
\hline Primer & Primer sequences 5'-3' & Melting temperature $\left({ }^{\circ} \mathrm{C}\right)$ & Annealing temperature $\left({ }^{\circ} \mathrm{C}\right)$ & $\begin{array}{l}\text { Approximate range } \\
\text { of band size (bp) }\end{array}$ & $\begin{array}{c}\text { Number of } \\
\text { bands amplified }\end{array}$ \\
\hline PCP-1 & $(\mathrm{GAC})_{5}$ & 56.7 & 51.7 & $650-1800$ & 7 \\
\hline PCP-2 & $(\mathrm{AGG})_{6}$ & 62.4 & 57.4 & $700-1815$ & 8 \\
\hline PCP-3 & $(\mathrm{GTGC})_{4}$ & 71.1 & 66.1 & $400-750$ & 4 \\
\hline PCP-5 & $(\mathrm{GA})_{9} \mathrm{~T}$ & 48 & 43 & $450-1185$ & 5 \\
\hline PCP-6 & $(\mathrm{GACA})_{4}$ & 45 & 40 & $500-1600$ & 8 \\
\hline PCP-8 & $(\mathrm{GTG})_{5}$ & 57.2 & 52.2 & $600-1500$ & 6 \\
\hline PCP-9 & $(\mathrm{GACAC})_{4}$ & 65.7 & 60.7 & $300-1000$ & 4 \\
\hline Oligo-3(b) & $(\mathrm{GACA})_{4}$ & 48 & 43 & $550-1700$ & 7 \\
\hline Oligo-4(a) & $(\mathrm{GACA})_{4} \mathrm{~T}$ & 50 & 45 & $800-1500$ & 3 \\
\hline Oligo-4(b) & $\mathrm{T}(\mathrm{GACA})_{4}$ & 50 & 45 & $500-1200$ & 5 \\
\hline Oligo-11(a) & $\mathrm{G}(\mathrm{CTGT})_{4}$ & 52 & 47 & $900-2500$ & 5 \\
\hline
\end{tabular}


has potential to create a pool of plants, which can be useful for reclamation of wild as well as the captive population of this medicinal plant species. This plant population with uniform genetic makeup generated through tissue culture can meet the increasing demand of local Vaidyas, pharmaceutical companies, and drug discovery research to a desirable extent.

\section{ACKNOWLEDGMENTS}

BB acknowledged UGC, New Delhi, for funding through Rajiv Gandhi National Fellowship (RGNF) to carry out this work. SR, DPB, PKJ, and SKN acknowledged the financial support of the Department of Science and Technology, Government of India, to the Department of Botany, Ravenshaw University, Cuttack, through DST-FIST grant (SR/FST/LSI-017-2010).

\section{REFERENCES}

1. Chopra RN, Chopra IC, Verma BS. Supplement to glossary of Indian medicinal plants. New Delhi: CSIR; 1969.

2. Chanda S, Sarethy IP, De B, Singh K. Paederia foetida-a promising ethno-medicinal tribal plant of north-eastern India. J Forestry Res 2013;24:801-8.

3. Kumar V, Anwar F, Ahmed D, Verma A, Ahmed A, Damanhouri ZA, et al. Paederia foetida Linn. Leaf extract: An antihyperlipidemic, antihyperglycaemic and antioxidant activity. BMC Complement Altern Med 2014;14:76.

4. De S, Ravishankar B, Bhavsar GC. Investigation of the antiinflammatory effects of Paederia foetida. J Ethnopharmacol 1994:43:31-8.

5. Afroz S, Alamgir M, Khan MT, Jabbar S, Nahar N, Choudhuri MS. Antidiarrhoeal activity of the ethanol extract of Paederia foetida Linn. (Rubiaceae). J Ethnopharmacol 2006;105:125-30.

6. Osman H, Rahim AA, Isa NM, Bakhir NM. Antioxidant activity and phenolic content of Paederia foetida and Syzygium aqueum. Molecules 2009;14:970-8.

7. Begum J, Yusuf M, Chowdhury JU, Khan S, Anwar MN. Antifungal activity of forty higher plants against phytopathogenic fungi. Bangladesh J Microbiol 2007;24:76-8.

8. Srivastava SK, Srivastava N. In vitro multiplication of Paedaria foetida L.-a rare medicinal plant. J Plant Biochem Biotechnol 2004;13:89-91.

9. Ved DK, Kinhal GA, Ravikumar K, Shankar RV, Sumathi R, Mahapatra AK, et al. Conservation Assessment and Management Prioritization for Medicinal Plants of Orissa. Bhubaneswar, Bangalore: Regional Plant Research Centre and Foundation for Revitalization of Local Health Traditions; 2008.

10. Aquilar NO. Paederia foetida L. In: Van Valkenburg JL, Bunyapraphatsara N, editors. Plant Resource of South-East Asia. Medicinal and Poisonous Plants. Ledien, The Netherlands: Blackhuys Publisher; 2001. p. 396-400.

11. Alam M, Azam FM, Kari MM, Rehana F, Sharmin N, Kalpana MK, et al. In vitro regeneration of Paederia foetida; a widely used medicinal vine in Bangladesh. Am Eur J Sustain Agric 2010;4:164-9.

12. Amin MN, Rahaman MM, Manik MS. In vitro clonal propagation of Paederia foetida L.-a medicinal plant in Bangladesh. Plant Tissue Cult 2003;13:117-23.

13. Thirupathi M, Srinivas D, Reddy JK. High frequency of multiple shoots induction in Paederia foetida L. a rare medicinal plant. Plant 2013;1:60-5.

14. Behera B, Behera S, Jena PK, Barik DP, Naik SK. Adventitious shoot organogenesis and plant regeneration from internode explants of Paederia foetida L.: A valuable medicinal plant. Biosci Biotechnol
Res Asia 2017;14:893-900.

15. Mishra T, Goyal AK, Middha SK, Sen A. Antioxidant properties of Canna edulis Ker- Gwal. Indian J Nat Prod Resour 2011;2:315-21.

16. Hassan HM, Nahal MM. In vitro antioxidant and free radical scavenging activities of red grapes seed extracts. Glob J Biotechnol Biochem 2010;5:106-15.

17. Ksouri R, Falleh H, Megdiche W, Trabelsi N, Mhamdi B, Chaieb K, et al. Antioxidant and antimicrobial activities of the edible medicinal halophyte Tamarix gallica L. and related polyphenolic constituents. Food Chem Toxicol 2009;47:2083-91.

18. Kalaivani T, Mathew L. Free radical scavenging activity from leaves of Acacia nilotica (L.) Wild. ex Delile, an Indian medicinal tree. Food Chem Toxicol 2010;48:298-305.

19. Nayak R, Panda A, Samanta L, Sahoo S. Phytochemical analysis of antioxidants from Abutilon indicum L. and Paederia foetida L. supported by TLC, FTIR and NMR studies. Int J Sci Res 2013;4:1312-8.

20. Krishna H, Alizadeh M, Singh D, Singh U, Chauhan N, Eftekhari M, et al. Somaclonal variations and their applications in horticultural crops improvement. 3 Biotech 2016;6:54.

21. Murashige T, Skoog F. A revised medium for rapid growth and bioassays with tobacco tissue cultures. Physiol Plant 1962;15:473-97.

22. Farhan H, Rammal H, Hijazi A, Hamad H, Daher A, Reda M, et al. In vitro antioxidant activity of ethanolic and aqueous extracts from crude Malva parviflora L. grown in Lebanon. Asian J Pharm Clin Res 2012;5:234-8.

23. Patra JK, Dhal NK, Thatoi HN. In vitro bioactivity and phytochemical screening of Suaeda maritima (Dumort): A mangrove associate from Bhitarkanika, India. Asian Pac J Trop Med 2011;4:727-34.

24. Gomez KA, Gomez AA. Statistical Procedure for Agricultural Research. New York: Wiley; 1984.

25. Doyle JJ, Doyle J. Isolation of plant DNA from fresh tissue. Focus 1990;12:13-5.

26. Arab MM, Yadollahi A, Shojaeiyan A, Shokri S, Ghojah SM. Effects of nutrient media, different cytokinin types and their concentrations on in vitro multiplication of $\mathrm{G} \times \mathrm{N} 15$ (hybrid of almond $\times$ peach) vegetative rootstock. J Gen Eng Biotechnol 2014;12:81-7.

27. Thorpe T, Stasolla C, Yeung EC, de Klerk GJ, Roberts A, George EF. The components of plant tissue culture Media II: Organic additions, osmotic and $\mathrm{pH}$ effects, and support systems. In: George EF, Hall MA, de Klerk GJ, editors. Plant Propagation by Tissue Culture. The Netherlands: Springer; 2008. p. 115-73.

28. Nunes EC, Castilho CV, Mareno FN, Viana AM. In vitro culture of Cedrela fissilis Vellozo (Meliaceae). Plant Cell Tissue Organ Cult 2002;70:259-68.

29. Dalal NV, Rai VR. In vitro propagation of Oroxylum indicum Vent. A medicinally important forest tree. J Forestry Res 2004;9:61-5.

30. Amoo SO, Finnie JF, Van Staden J. The role of meta-topolins in alleviating micropropagation problems. Plant Growth Regul 2011;63:197-206.

31. Kaminek M, Motyka V, Vankova R. Regulation of cytokinin content in plant cells. Physiol Plant 1997;101:689-700.

32. Kieber JJ, Schaller GE. Cytokinins. The Arabidopsis Book. 2014. 12:e168. doi: 10.1199/tab.0168.

33. Anand SP, Jeyachandran R. In vitro multiple shoot regeneration from nodal explants of Zehneria scabra (L. f.) Sonder-an important medicinal climber. Plant Tissue Cult 2004;14:101-6.

34. Nayak SA, Kumar S, Satapathy K, Moharana A, Behera B, Barik DP, et al. In vitro plant regeneration from cotyledonary nodes of Withania somnifera (L.) Dunal and assessment of clonal fidelity using RAPD and ISSR markers. Acta Physiol Plant 2013;35:195-203.

35. Baskar R, Rajeswari V, Kumar TS. In vitro antioxidant studies in leaves of Annona species. Indian J Exp Biol 2007;45:480-5.

36. Graf E. Antioxidant potential of ferulic acid. Free Radic Biol Med 1992;13:435-48. 
37. Rath S, Patra JK, Mohapatra N, Mohanty G, Dutta S, Thatoi H. In vitro antibacterial and antioxidant studies of Croton roxburghii $\mathrm{L}$. from similipal biosphere reserve. Indian J Microbiol 2011;51:363-8.

38. Duncan RR. Tissue culture-induced variation and crop improvement. Adv Agron 1996;58:201-40.

39. Palombi MA, Damiano C. Comparison between RAPD and SSR molecular markers in detecting genetic variation in kiwifruit (Actinidia deliciosa A. Chev). Plant Cell Rep 2002;20:1061-6.

40. Devarumath RM, Nandy S, Rani V, Marimuthu S, Muraleedharana N, Raina SN. RAPD, ISSR and RFLP fingerprints as useful markers to evaluate genetic integrity of micropropagated plants of three diploid and triploid elite tea clones representing Camellia sinenis (China type) and C. assamica spp. assamica (Assam-India Type). Plant Cell Rep 2002;21:166-73.

41. Prakash L, Middha SK, Mohanty SK, Swamy MK. Micropropagation and validation of genetic and biochemical fidelity among regenerants of Nothapodytes nimmoniana (Graham) Mabb. Employing ISSR markers and HPLC. 3 Biotech 2016;6:171.

42. Sharma MM, Verma RN, Singh A, Batra A. Assessment of clonal fidelity of Tylophora indica (Burm. F.) merrill "in vitro" plantlets by ISSR molecular markers.SpringerPlus 2014;3:400.

43. Lakshmanan V, Venkataramareddy SR, Neelwarne N. Molecular analysis of genetic stability in long-term micropropagated shoots of banana using RAPD and ISSR markers. Electron J Biotechnol 2007;15:1-8.

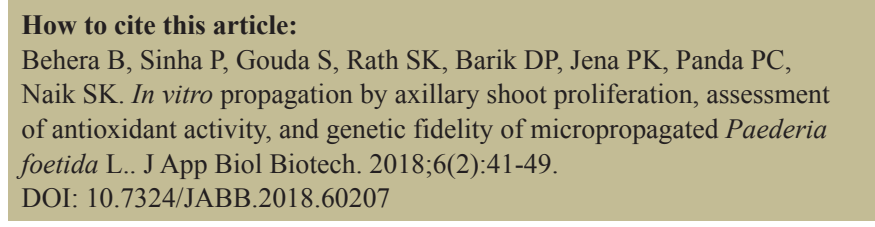

